\title{
Institutional Efficiency and Attraction of Foreign Direct Investment to Developing Countries
}

\author{
Karima Sayari ${ }^{1}$ \\ ${ }^{1}$ Managerial and Financial Sciences Department, Al-Zahra College for Women, Muscat, Sultanate of Oman \\ Correspondence: Karima Sayari, Assistant Professor., Managerial and Financial Sciences Department, Al-Zahra \\ College for Women, Muscat, Sultanate of Oman. Tel: 968-9640-2502. E-mail: karima_sayari@yahoo.fr
}

Received: April 21, 2019

Accepted: May 24, 2019

Online Published: June 5, 2019

doi:10.5539/ijef.v11n7p54

URL: https://doi.org/10.5539/ijef.v11n7p54

\begin{abstract}
The paper estimates the impact of institutions' quality on the attraction of foreign direct investment (FDI) to developing countries. Data Envelopment Analysis (DEA) was used to develop a new measure of quality of institutions: Institutional Efficiency Index (IEI). In order to appraise quantitatively the effect of institutional quality on FDI entry, we used a panel data regression analysis on a dataset covering 40 countries from different developing regions for which the necessary data were accessible during the period 2011-2015. The paper argues that the institutional efficiency, as a measure of institutional quality, enhances the attractiveness of developing countries to FDI.

The results of this paper suggest that FDI is mainly determined by institutional quality. A host country endowed with a high quality of institutions will be more attractive to foreign investors. In order to improve their competitiveness in term of attraction of foreign investment, developing countries should work more on providing a stable environment as well as on the transparency of policy implementation regarding the entry of multinational companies.
\end{abstract}

Keywords: institutional efficiency index, DEA method, measure of institution's quality, FDI entry

\section{Introduction}

Foreign direct investment has been proved as an essential element in stimulating economic growth in developing countries. In fact, FDI gives the host country the capability to invest beyond the level of their home savings. Benefits of foreign direct investment are transfer of capital, technology and knowledge, improving management capacity, increasing employment, improving competitiveness and achieving a favorable balance of payments. Because of these advantages and in a globalized and changing international environment, the competition among countries in term of attraction of foreign direct investment has been intensified. The availability and similarity of economic (traditional) factors make investors base their localization decision on what make these countries distinguish in term of their institutional framework. One of the greatest significant dynamics in attracting foreign direct investment, along with the economic factors, are the political stability and low country risk.

Recently, investors have been concentrating more on the quality of institutions as an important determinant of FDI. The paper examines the reasons of differences among countries in their attractiveness and try to understand why some countries are more attractive for investors than others. By developing a new measure of institutional quality, the paper examines the importance of institutional factors over economic ones. The result of this paper is essential in developing new concepts. In addition to the existing literature, we tried to construct a new index called the institutional efficiency index using DEA method. The index measures the quality of institutions and includes various dimensions, as the decisions of foreign investors might depend on different features of institutions. Furthermore, the new measure of institutional quality developed in the paper serves as an explanatory variable for FDI entry. The new measure which is an aggregate index takes into consideration the common institutional factors raised in FDI determinants literature. The rest of the paper is organized as follows. Part 2 affords a brief literature on the impact of institutional quality on FDI entry. Part 3 clarifies the econometric methodology and designates the data. Part 4 presents the econometric findings. Finally, Part 5 concludes by debating policy implications of our findings. 


\section{Literature Review}

\subsection{Quality of Institutions Measures (Independent Variable)}

Starting from the 1990s, the literature on economic advance has been transformed by concentrating on the domestic institutions' quality of as a key clarification of cross-country differences in both growth rates and income per capita. Well-organized protection of civil and property rights, extended economic and political freedom and low level of corruption have been in particular shown to be associated with higher prosperity. Many researchers examined the impact of quality of institutions on FDI. Most of them used only one aspect of the institutional framework, like corruption, political stability, but this alone cannot provide enough evidence to generalize the outcome of the study. Consistently, Globerman and Shapiro (2002) approximate the impact of governance infrastructure on both entries and outflows of FDI. They find good governance influences positively both FDI inflows and outflows.

Indeed, the judgment on institution's quality can be subject to debates. One reason comes from the way data on institutions is obtained through local specialists, various observations or an investigation in a country. A second reason is the selection of variables to be included in the governance indexes. The third reason is related to methods of aggregation. Generally aggregating indexes use simple linear aggregation of institutional variables data to create an aggregate institutional quality score. These aggregation approaches have drawn several drawbacks, especially the subjective choice of weights of variables constructing the index. Different weights can change the result of the index. However; using the DEA method minimize the problems of aggregating indexes.

Data envelopment analysis initially developed by Charnes et al. (1978), is a linear programming approach for evaluating the relative technical efficiency for each member of a set of peer decision making units (DMUs). DEA have been used to weigh the performance in many fields. Traditional DEA model dealt only with positive data of inputs and outputs. But governance data which will be used in this study to measure the institutional efficiency contains some negative ones. The continuing researches in DEA models managed to include data with positive and/ or negative data. We can state Portela et al. (2004) developed the RDM model. Sharp and al (2006) introduced (MSBN). Emrouznejad et al. (2010) suggested a semi-oriented radial measure (SORM), which is appropriate to data sets and comprises variables which can take together negative and positive values.

The "institutional efficiency index" developed in this paper used Kaufman's indicators database. These indicators involve a wide variety of institutional characteristics. More explanation on the index, governance indictors used and classification in input/ output will be in the following section (methods).

\subsection{Inflation}

Inflation causes higher irregular prices and rises the production cost and has an adverse influence on the FDI (Brewer, 1993; and Urata \& Kawai, 2000). Furthermore, a high inflation rate replicates macroeconomic instability, which rises ambiguity and insecurity and makes it less appealing to FDI.

\subsection{Economic Openness}

Economic openness highlights the importance of exchanges between countries. An open economy is the one which allows a free trade and doesn't impose any restrictions. This absence of restriction encourages foreign entrepreneurs to localize their investments in such country. So, an expected positive relationship with FDI.

\subsection{Exchange Rate}

Exchange rate regime is an important factor that affects investment decision in a country. A devaluation of the currency in the host country makes the asset price less expensive, but it also lessens the yield the investor obtains in foreign currency. Empirical studies of FDI seemed to confirm this. Contrarily, some other studies found that host-country exchange rate depreciations is a contributing factor to inward foreign investment booms.

\subsection{Real Interest Rate}

The FDI model proposes that the interest rate differential between host and home countries may have an encouraging impact on FDI. In fact, the interest rate is the cost of money charged on the borrower of money. Collecting money at low interest rate in the source country improves the competitiveness over competitors in host country. Mixed results are presented by previous works. In fact some studies found that a relatively high real interest rate affect positively FDI (Gross \& Trevino, 1996). However, the influence can be negative if the foreign investors depend on host country's capital market for raising FDI fund. 


\section{Methods}

\subsection{Data Collection}

Considering the development of a new institutional quality measure for this study, we choose the DEA method to construct an index that we name institutional efficiency index (used as independent variable in our model). To develop this index, Data are collected from World Governance Indicators by World Bank. Concerning the other dependent variables, data are gathered from World Development Indicators (World Bank). We also obtained the aggregate value data of FDI inflows for our sample of 40 countries from World Investment Report. The sample contains countries from different developing regions. Regarding the FDI entry, the common feature of these countries is the challenge to improve their competitiveness in attracting foreign investment since it is considered one of the most stable component of capital movements to this group of countries. Furthermore, these countries which relied more on their natural resources in attracting FDI, showed a decline in their FDI flows since 2011. This can be explained by the fact that the traditional determinants played no more roles as an appealing factor.

The period of the study (2011-2015) denotes a global economic fragility and policy uncertainty. In addition, the period covers the wave of Arab Spring which affected some countries of the study sample. (Tunisia, Libya, Egypt...) and affected significantly FDI entry. The availability of data during the period and for all countries of the sample was very important to have a balanced panel.

The major restraint to this study is that we miss to gather long observation for governance indicators to construct the institutional efficiency index for the sample chosen.

\subsection{Institutional Efficiency Index (IEI) as a Measure of Institution's Quality}

In order to develop a measure of institutions' quality that will be used as an explanatory variable for FDI entry, we use Kaufman 'indicators which provide six dimensions of governance:

1) Voice and accountability (VA), the magnitude to which a country's public are able to contribute in choosing their government, as well as all forms of freedom.

2) Political stability and absence of violence (PV), observations of the probability that the government will be weakened by illegal or violent means.

3) Government effectiveness (GE), the quality of public services, the grade of its freedom from political pressures, the reputation of policy preparation and implementation, and the reliability of the government's promise.

4) Regulatory quality (RQ), the ability of the regime to express and perform sound policies and regulations favorable to the expansion of the private sector.

5) Rule of law (RL), the extent to which agents have confidence in and abide by the rules of society, and in particular the quality of contract enforcement, the police, and the courts, as well as the likelihood of crime and violence.

6) Control of corruption (CC), the extent to which public power is trained for private gain as well as "capture" of the state by elites and private interests.

These indicators are classified into input and output. Every indicator that encourages the entry of FDI is considered as an output that needs to be maximized. Indicators that have to be minimized are the ones discouraging FDI and are considered as input. To construct the institutional efficiency index, we consider one input (corruption) and 5 outputs (Political stability, Government effectiveness, and Regulatory quality, Rule of law and Voice and accountability). The ranking and the relative score of efficiency of the sample are summarized in table 1 below. Although, results do not indicate a big change over the period, there are some countries which ameliorated their efficiency (Egypt, Brazil, Zambia, etc.). Others have lost their efficiency (Turkey, Jordan, Ecuador). 
Table 1. Institutional efficiency index of developing countries (2011-2015)

\begin{tabular}{|c|c|c|c|c|c|c|c|c|c|c|}
\hline \multirow[b]{2}{*}{ Countries } & \multicolumn{2}{|c|}{2011} & \multicolumn{2}{|c|}{2012} & \multicolumn{2}{|c|}{2013} & \multicolumn{2}{|c|}{2014} & \multicolumn{2}{|c|}{2015} \\
\hline & Score & ranking & Score & ranking & Score & ranking & Score & ranking & Score & ranking \\
\hline Argentina & 1 & 1 & 1 & 1 & 1 & 1 & 0,98752 & 21 & 1 & 1 \\
\hline Chili & 1 & 1 & 1 & 1 & 1 & 1 & 1 & 1 & 1 & 1 \\
\hline Ecuador & 1 & 1 & 0,979 & 19 & 0.94542 & 27 & 0.88953 & 32 & 0.80824 & 38 \\
\hline Indonesia & 1 & 1 & 0,972 & 20 & 1 & 1 & 0.98752 & 21 & 0.95195 & 23 \\
\hline Jordan & 1 & 1 & 0,914 & 28 & 0.87027 & 37 & 0.90347 & 30 & 0.93251 & 27 \\
\hline Kenya & 1 & 1 & 1 & 1 & 1 & 1 & 1 & 1 & 1 & 1 \\
\hline Malaysia & 1 & 1 & 1 & 1 & 1 & 1 & 1 & 1 & 1 & 1 \\
\hline Mali & 1 & 1 & 1 & 1 & 1 & 1 & 1 & 1 & 1 & 1 \\
\hline Namibia & 1 & 1 & 1 & 1 & 1 & 1 & 1 & 1 & 1 & 1 \\
\hline Oman & 1 & 1 & 1 & 1 & 1 & 1 & 1 & 1 & 0.99498 & 17 \\
\hline Paraguay & 1 & 1 & 1 & 1 & 1 & 1 & 1 & 1 & 1 & 1 \\
\hline Philippines & 1 & 1 & 0.98672 & 16 & 0.99535 & 20 & 1 & 1 & 1 & 1 \\
\hline Tanzania & 1 & 1 & 1 & 1 & 0.96514 & 23 & 1 & 1 & 0.89681 & 32 \\
\hline Turkey & 1 & 1 & 0.97238 & 21 & 1 & 1 & 0.95665 & 25 & 0.92713 & 28 \\
\hline Uganda & 1 & 1 & 1 & 1 & 1 & 1 & 1 & 1 & 0.98586 & 19 \\
\hline Uruguay & 1 & 1 & 1 & 1 & 1 & 1 & 0.99694 & 20 & 1 & 1 \\
\hline UAE & 0.984 & 17 & 0.87818 & 31 & 0.87447 & 35 & 0.78959 & 39 & 0.84056 & 35 \\
\hline Honduras & 0.981 & 18 & 0.93491 & 24 & 0.94204 & 28 & 0.90756 & 28 & 0.96309 & 22 \\
\hline Peru & 0.977 & 19 & 0.89709 & 29 & 1 & 1 & 0.97908 & 3 & 0.93875 & 26 \\
\hline Egypt & 0.976 & 20 & 0.99473 & 15 & 1 & 1 & 1 & 1 & 1 & 1 \\
\hline Zambia & 0.975 & 21 & 1 & 1 & 1 & 1 & 1 & 1 & 1 & 1 \\
\hline Brazil & 0.969 & 22 & 0.98012 & 18 & 0.97552 & 22 & 1 & 1 & 1 & 1 \\
\hline Bahrain & 0.962 & 23 & 0.95074 & 22 & 1 & 1 & 0.97145 & 24 & 0.95073 & 24 \\
\hline Columbia & 0.952 & 24 & 0.92879 & 25 & 0.90183 & 30 & 0.87312 & 33 & 0.90642 & 29 \\
\hline Senegal & 0.946 & 25 & 0.94234 & 23 & 0.94568 & 26 & 0.94866 & 26 & 0.94155 & 25 \\
\hline China & 0.943 & 26 & 0.98099 & 17 & 1 & 1 & 1 & 1 & 1 & 1 \\
\hline Morocco & 0.916 & 27 & 0.88523 & 30 & 0.88984 & 34 & 0.86595 & 34 & 0.89697 & 31 \\
\hline Bangladesh & 0.911 & 28 & 1 & 1 & 1 & 1 & 1 & 1 & 1 & 1 \\
\hline Kuwait & 0.888 & 29 & 0.86659 & 33 & 0.89358 & 32 & 0.90529 & 29 & 0.99517 & 16 \\
\hline Mauritania & 0.885 & 30 & 0.77263 & 38 & 0.8977 & 31 & 0.84789 & 37 & 0.9914 & 18 \\
\hline Tunisia & 0.8611 & 31 & 0.86423 & 34 & 0.85651 & 39 & 0.93718 & 27 & 0.98272 & 20 \\
\hline Pakistan & 0.838 & 32 & 0.85564 & 36 & 0.99209 & 21 & 1 & 1 & 0.96461 & 21 \\
\hline Chad & 0.833 & 33 & 0.91522 & 27 & 0.92127 & 29 & 1 & 1 & 0.83427 & 36 \\
\hline Syria & 0.833 & 34 & 0.85579 & 35 & 0.94883 & 25 & 0.89139 & 31 & 0.89906 & 30 \\
\hline Algeria & 0.83181 & 35 & 0.83055 & 37 & 0.8731 & 36 & 0.81995 & 38 & 0.81734 & 37 \\
\hline Saudia Arabia & 0.83011 & 36 & 0.87741 & 32 & 0.89355 & 33 & 0.8479 & 36 & 0.87555 & 34 \\
\hline Nepal & 0.82751 & 37 & 0.75381 & 40 & 0.8633 & 38 & 0.85824 & 35 & 0.8932 & 33 \\
\hline Libya & 0.79451 & 38 & 0.9222 & 26 & 1 & 1 & 1 & 1 & 1 & 1 \\
\hline Sudan & 0.76088 & 39 & 1 & 1 & 0.96211 & 24 & 1 & 1 & 0.80499 & 39 \\
\hline Yemen & 0.75334 & 40 & 0.76397 & 39 & 0.80199 & 40 & 0.76047 & 40 & 0.78661 & 40 \\
\hline
\end{tabular}

Source: Author's Fieldwork.

The table above summarizes the result of the institutional efficiency index calculated by the software DEA solver. For each year, we have a column that lists the score and a column that lists the ranking of countries in our sample.

For the score column, a score of 1 means that the corresponding country is efficient in term of maximization of favorable determinants responsible to improve the attraction of the country to FDI and minimization of the one who hamper the FDI inflows. The lower the score, the less efficient is the country and the lower is its opportunity to attract FDI.

\subsection{Empirical Model}

Practical studies try to explicate the FDI arrivals to developing countries by using various methods: cross-sectional regressions, panel estimation methods and econometric analysis in chronological series. we 
propose to use a dynamic model of panel data. The examination is based on a panel of 40 developing countries over 2011-2015. The dependent variable, FDI flows, is seized by the annual data for the net FDI inflows. Following the literature and empirical studies, the key determinants of FDI can be synthesized in the following dynamic model:

$$
F D I_{i t}=\beta_{0+} \beta_{1} F D I_{i t-1}+\beta_{2} I E I_{i t}+\beta_{3} \text { openness }_{i t}+\beta_{4} \text { exchange rate }_{i t}+\beta_{5} \text { interest rate }_{i t}+\beta_{6} \text { inflation }_{i t}+\mu_{i t}
$$

Where:

FDI: the level of FDI is the dependent variable;

i: index going from 1 to 40 and indicates the individual (country);

$\mathrm{t}$ : is the year from 2011 to 2015,1 to 5 and indicates the year;

$\beta_{0}$ is the intercept; $\beta_{1}, \beta_{2}, \beta_{3}, \beta_{4}, \beta_{5}, \beta_{6}$ are the slope; $\mu_{\mathrm{it}}$ is the error term.

The dynamic model contains the lagged net inward FDI as an explanatory variable. This entails that there is a correlation between the explanatory variables and $\mu_{\mathrm{it}-1}$. The lagged error term $\left(\mu_{\mathrm{it}-1}\right)$ is a function of the country fixed effects $\mu_{\mathrm{it}}$. The appropriate and preferred estimator for the dynamic model is the GMM estimator proposed by Arellano and Bond (1991). This estimator removes the country fixed/time-invariant effects via differencing.

\section{Results}

The estimation of the model is done in two steps. In the first step, we consider only economic variables. In a second step, we introduce the effect of institutional determinants measured by (IEI). The result of estimation given by the appropriate econometric software (Stata) are as follows;

Table 2. Regression result without institutional efficiency index

\begin{tabular}{lccc}
\hline Explanatory variables & Coefficients & t- statistic & Probability \\
\hline$\beta_{0}$ & 1.342182 & 1.11 & 0.267 \\
FDI $_{\text {it-1 }}$ & $.8622201^{*}$ & 4.26 & 0.000 \\
Openness & .0001781 & 0.00 & 1.000 \\
Exchange rate & -.0013291 & -0.29 & 0.772 \\
Interest rate & -.0049958 & -0.23 & 0.820 \\
Inflation & $-.0243778^{* *}$ & -3.29 & 0.001 \\
\hline
\end{tabular}

$*$ significant at $1 \%$, ** significant at $5 \%$.

The above result deals only with economic variables. In a first step of the analysis, we tried to assess the impact of traditional (mainly economic) factors on the FDI entry. The statistically significant positive coefficients of lagged values of FDI flows show that FDI flows are influenced by the previous year's FDI (Agglomeration effect). And this can be explained by the signal effect which can attract new investors. In fact, new investors will be more attracted to countries that experienced large inflows in previous periods. Our result has established the existence of an adjustment process for the FDI entries.

Furthermore, the coefficient $(0.862)$ has shown that the speed of adjustment is important. This result confirms that the explanation of FDI going through the process of partial adjustment.

To test the impact of institutional determinants on the attraction of the FDI, we introduced the institutional efficiency index (IEI) in the second estimation. The result is summarized in table 3.

Table 3. Regression result with institutional efficiency index

\begin{tabular}{lccc}
\hline Explanatory variables & Coefficients & t- statistic & Probability \\
\hline$\beta_{0}$ & 2.847326 & 1.05 & 0.292 \\
FDI $_{\text {it-1 }}$ & 0.2139319 & 1.22 & 0.222 \\
Institutional Efficiency & $4.594611^{*}$ & 2.68 & 0.007 \\
Openness & $-3.617341^{*}$ & -3.74 & 0.000 \\
Exchange rate & -0.0009585 & -0.43 & 0.664 \\
Interest rate & 0.0053835 & 0.28 & 0.779 \\
Inflation & $-0.0343685^{*}$ & -5.06 & 0.000 \\
\hline
\end{tabular}

$*$ significant at $1 \%, * *$ significant at $5 \%$. 
Table 3 results showed that with the introduction of institutional variable, lagged values FDI is no longer significant. This can be explained by the fact that institutional variables are dynamic and flexible and justify the dynamism of the model. Openness affects negatively inwards FDI. This result reflects the persistence of obstacles to free transactions in some developing countries, especially in Africa. Inflation affects negatively FDI entry, a high rate of inflation discourages foreign investors. This result is consistent with other studies (Pravin, 2012).

We do not find a significant relationship between real interest rate and exchange rate. This can be explained by the fact that investors are not seeking to raise money from developing host countries. The low contribution of economic (traditional factors) in explaining the variability of FDI support our result concerning the role of institutional quality in attraction of foreign investors (Pravin, 2012).

\section{Conclusion}

The paper outlines the relevance of quality of institutions for FDI inflows in developing countries. Foreign investors are attracted to host countries which guarantee a stable and predictable political environment that safeguards private investors from any unexpected event. In addition to economic factors, the institutional quality gives a positive signal to foreign investors. A transparent investment climate, which protects their laws and benefits is more attractive for them. Moreover, the paper contributes to the existing literature on FDI determinants and specifically to the role of institutional determinants in different ways. First, the development of a measure of institutional quality using the DEA method. Second, previous studies used governance indicators separately to assess the effect of institutions on the attraction of FDI. Whereas, in our paper these indicators are used to construct an aggregate index and this provides a new measure of quality of institutions and consequently, a new determinant of FDI. Third. The index is used as an independent variable in a panel regression for a sample of 40 countries from different developing regions.

Our result might assist developing countries that wish to increase their FDI inflows, which in their turns should work to enhance governance, fight corruption at all levels and address luck of transparency. While resources and classical factors remain an important determinant of FDI inflows, quality of institutions is acquiring the key role for the attractiveness of these countries. Developing countries have to undertake some changes to develop the business environment in order to satisfy public spending on infrastructure. The findings point to a large and ongoing research agenda. One issue is to define the new role of institutions in developing countries after the wave of democratic transitions which spread from one country to another.

\section{References}

Asiedu, E. (2002). On the Determinants of Foreign Direct Investment to Developing Countries: Is Africa Different. World Development, 30(1), 107-119. https://doi.org/10.1016/S0305-750X(01)00100-0

Asiedu, E., \& Kwabena, G. B. (2008). The Impact of Trade and Investment Liberalization on Foreign Direct Investment, Wages and Employment in Sub-Saharan Africa. African Development Review, 20(1), 49-66. https://doi.org/10.1111/j.1467-8268.2008.00176.x

Bénassy- Quéré, A., Maylis, C., \& Thierry, M. (2007). Institutional determinants of FDI. World Economy, 30(5), https://doi.org/10.1111/j.1467-9701.2007.01022.x

Bevan, A., Estrin, S., \& Klaus, M. (2004). Foreign investment location and institutional development in transition economies. International Business Review, 13. https://doi.org/10.1016/j.ibusrev.2003.05.005

Charnes, A., Cooper, W. W., \& Rhodes, E. (1978). Measuring the Efficiency of Decision Making Units. European Journal of Operational Research, 2. https://doi.org/10.1016/0377-2217(78)90138-8

Charnes, A., Cooper, W. W., Lewin, A. Y., \& Seiford, L. M. (1994). Data Envelopment Analysis: Theory, Methodology and Application. Boston/Dordrecht/London: Kluwer, Academic Publishers. https://doi.org/10.1007/978-94-011-0637-5

Cook, W. D., \& Seiford, L. M. (2008). Data envelopment analysis (DEA) - Thirty years on. European Journal of Operational Research, 192(1). https://doi.org/10.1016/j.ejor.2008.01.032

Cooper, W. W., Seiford, L. M., \& Tone, K. (2000). Data Envelopment Analysis: A Comprehensive Text with Models, Applications, References and DEA-Solver Software. Boston: Kluwer, Academic Publishers.

Dollar, D., \& Kraay, A. (2003). Institutions, trade, and growth. World Bank WPS 3004. https://doi.org/10.1016/S0304-3932(02)00206-4

Dollar, D., Hallward-Driemeier, M., \& Mengistae, T. (2004). Investment climate and international integration. 
World Bank WPS 3323.

Drabek, Z., \& Payne, W. (2001). The Impact of Transparency on Foreign Direct Investment. Staff Working Paper ERAD-99-02.

Dunning, J. H. (2002). Determinants of foreign direct investment: Globalisation induced changes and the role of FDI policies. Paper presented at the Annual Bank Conference on Development Economists in Europe.

Emrouznejad, A., Anouze, A. L., \& Thanassoulis, E. (2010). A semi-oriented radial measure for measuring the efficiency of decision making units with negative data, using DEA. European Journal of Operational Research, 200(1), 297-304. https://doi.org/10.1016/j.ejor.2009.01.001

Engerman, S. L., \& Sokolof, K. L. (2003). Institutional and non institutional explanations of economic differences. NBER, WPS 9989. https://doi.org/10.3386/w9989

Fabry, N., \& Zeghni, S. (2007). FDI in the New European Neighbors of Southern Europe: A quest of institutions-based attractiveness. Université de Marne-la-Vallée, MPRA Paper $n^{\circ} 1109$.

Gattoufi, S., Amin, G. R., \& Emrouznejad, A. (2014). A new inverse DEA method for merging banks. IMA Journal of Management Mathematics, 25, 73-87. https://doi.org/10.1093/imaman/dps027

Global Competitiveness Report. (2003/2004). World Economic Forum.

Globerman, S., \& Shapiro, D. (2002a). Governance infrastructure and US Foreign Direct Investment. Journal of International Business Studies. https://doi.org/10.1057/palgrave.jibs.8400001

Globerman, S., \& Shapiro, D. (2002b). Global Foreign Direct Investment flows: The role of Governance Infrastructure. World Development, 30(11). https://doi.org/10.1016/S0305-750X(02)00110-9

Hallward-Driemeier, M. (2003). Do bilateral treaties attract FDI? Only a bit ... and they could bite. World Bank, WPS 3121.

Hallward-Driemeier, M., Wallsten, S., \& Colin, X. Lixin. (2003). The investment Climate and the firm: Firm-Level Evidence from China. World Bank, WPS 3003.

Kaufmann, D., Kraay, A., \& Mastruzzi, M. (2007). Governance Matters VI: Aggregate and Individual Governance Indicators 1996-2006. World Bank, WPS 4280. https://doi.org/10.1596/1813-9450-4012

Li, Q., \& Resnick, A. (2003). Reversal of Fortunes: Democratic Institutions and FDI inflows to Developing countries. International Organization, 57(1). https://doi.org/10.1017/S0020818303571077

Naudé, W. (2004). The effects of policy, institutions and geography on economic growth in Africa: An econometric study based on cross-section and Panel Data. Journal of International Development, 16(6). https://doi.org/10.1002/jid.1129

Portela, M. S., Thanassoulis, E., \& Simpson, G. (2004). Negative data in DEA: a directional distance approach applied to bank branches. https://doi.org/10.1057/palgrave.jors.2601768

Pravin, J. (2012). Determinants of foreign direct investment in BRICS economies: Analysis of economic, institutional and political factor. Social and Behavioral Sciences, 37, 5-14. https://doi.org/10.1016/j.sbspro.2012.03.270

UNCTAD. (2017). World investment Report: Investment and the digital economy. New York.

\section{Copyrights}

Copyright for this article is retained by the author(s), with first publication rights granted to the journal.

This is an open-access article distributed under the terms and conditions of the Creative Commons Attribution license (http://creativecommons.org/licenses/by/4.0/). 